\title{
A PHOTOVOLTAIC SOLAR REFRIGERATION SYSTEM FOR VACCINE PRESERVATION IN REMOTE AREA
}

\author{
AYUSH KUMAR SINGH ${ }^{1}$, ANKIT KULSHRESTHA ${ }^{2}$ \& APARMIT SHIVAM ${ }^{3}$ \\ ${ }^{1}$ School of Engineering and Technology, Amity University Lucknow Campus, Uttar Pradesh, India \\ ${ }^{2,3}$ Department of Mechanical Engineering, B. B. D University, Lucknow, Uttar Pradesh, India
}

\begin{abstract}
As per WHO report most of the vaccines likes Diphtheria, Tetanus, Pertussis, Hepatitis A, Hepatitis B, Hib, Influenza, Meningococcal, Pneuernocqccal, Rotavirus are required to be preserved at refrigeration temperature such as $\left(2^{\circ} \mathrm{C}\right.$ to $\left.8^{\circ} \mathrm{C}\right)$. When the vaccines are preserved above or below the required temperature, the potency of a vaccine is lost resulting in loss of money, as vaccines are costly. In remote areas where electricity is not available, preservation of vaccines becomes a very serious concern. In order to provide the means to preserve the vaccines in remote areas, a portable refrigeration system working on photovoltaic effect has been designed and developed. The refrigeration system developed is of the dimension 24.50 " $\times 21.25$ " $\times 14$ " and has the capacity of 30 liters capable of maintaining the evaporator temperature of $0^{\circ} \mathrm{C}$ to $8^{\circ} \mathrm{C}$ for 9 hrs to 10 hrs once the battery is charged. The time taken by the battery to be charged is of the order $6 \mathrm{hrs}$ to $8 \mathrm{hrs}$. The coefficient of performance (COP) of a developed refrigeration system is 3.19 and the payback period as per techno-economic analysis is found to be 8 years 5 month 6 days.
\end{abstract}

KEYWORDS: Solar Photovoltaic, Vaccine, Remote Areas \& WHO

Received: May 12, 2018; Accepted: Jun 02, 2018; Published: Jul 03, 2018; Paper Id.: IJAERDDEC20181

\section{INTRODUCTION}

Among all vaccines many vaccines like as MMR, Diphtheria, Tetanus, Pertussis, Hepatitis A, Hepatitis B, Hib, Influenza, IPV, Meningococcal, Pneuernocqccal, Rotavirus are maintain between $0^{\circ} \mathrm{C}$ to $8^{\circ} \mathrm{C}$ temperature for proper preservation and some of the vaccines such as MMRV, Vricella, Zoster etc require freezer temperature as low as $-15^{\circ} \mathrm{c}$. When the vaccines are preserved above and below the required temperature, the potency of vaccines is lost. So excess heat and cold can damage the potency of vaccines. The damaged vaccine is very harmful to the health of children and adults alike. The cost of single vaccine could go unto $\$ 280$ so economic consequences of vaccine damage are equally important. The main reason for damage of vaccines is improper storage. So the preservation of vaccines at required temperature $\left(0^{\circ} \mathrm{C}\right.$ to $\left.8^{\circ} \mathrm{C}\right)$ is useful from two points of view (1) Economical Point Of View: - The cost of a single vaccine may go upto $\$ 285$, which is very expensive. In old vaccine system normally 2-3 vaccines will be damaged in one box during the whole day in summer season. (2) Health point of view: - The damaged vaccine is very harmful for patients. People can die on use of such damaged vaccines. Various researchers regarding the feasibility of a Vapor Compression Refrigerator powered by solar photovoltaic panels carry out a lot of work. Modi, A. et al. [2] fabricated a solar refrigeration system by using a 165 liter LG vapor compression refrigerator and then analyzed the performance of this refrigeration system. To operate this system following devices are used: 
- $\quad$ Two 12V 150 Ah Exide battery

- A charge control unit to overcome the problem of overcharging and deep discharging

- A transformer

- $\quad$ Four 75W solar panels.

On the basis of the various experiment, they conclude that from morning to afternoon COP decreases and the COP is maximum at $7 \mathrm{AM}$, which is 2.012. Economic feasibility of this refrigeration system is determined by using RET screen test. They conclude that solar panel is one of the most costly devices in this refrigeration system. The cost of producing $1 \mathrm{~W}$ power is Rs 80/- and this refrigeration system uses four $35 \mathrm{~W}$ solar panel costing Rs 11200/- hence it is necessary to provide the government subsidy on the solar panel. This whole experiment is done on the environmental condition of Jaipur city (India).

Kattakayam, T. A. and Shrinivasan, K. [3] analyzed the performance of $100 \mathrm{~W}$ AC power operated domestic vapor compression refrigeration system. To drive this refrigerator such component like solar photovoltaic panel, a battery and an inverter are used. By using these components a non-sinusoidal AC signal is formed. They analyzed the performance of this refrigerator and conclude that there no effect on the thermal performance by using non-sinusoidal AC signal. They also found that the thermal performance of this refrigerator is improved with the help of proper insulation of refrigerator and a vacuum insulated solar panel because of arresting heat losses. Vaccines are always stored away from the wall and door of the refrigerator. They suggest that it is necessary to improve the design of compressor motor of a domestic refrigerator.

Sarbu, A. and Sebarchievici, C. [4] studied different types of solar refrigeration system such as photovoltaic solar refrigerator, thermo-electric solar refrigerator, thermo-mechanical solar refrigerator (steam jet refrigerator), solar absorption refrigerator, solar adsorption refrigerator and desiccant solar cooling system. After this study, they compared the performance of all refrigerators. First, they compare the COP of the liquid desiccant solar cooling system and solid desiccant solar cooling system and they found that COP of the liquid desiccant solar cooling system is higher than a desiccant solar cooling system. By comparing the COP of absorption and adsorption solar refrigerator they found that the COP of absorption system is higher than adsorption system but operating temperature of absorption system is higher than adsorption system. Among all solar refrigeration system, the COP and operating temperature of a thermo-mechanical solar refrigerator (steam jet refrigeration system) are higher than other systems.

Nawaz, I. et al. [5] fabricated a solar refrigerator and then performed cost and eco-friendly analysis of this solar refrigerator. On the basis of cost analysis, it is trying to show that a solar power-operated refrigeration system is more economical in comparison to that refrigeration system which is operated with conventional electricity. Initial cost of the solar power refrigeration system is very high but after some time this refrigeration system is cheaper than electricity operated the system. In this paper, it shows that after five year this solar power system is cheaper than electricity operated system.

Biligili, M. [6] determined hourly simulation and performance of solar electric-vapor compression refrigeration system. This experiment was performed at different evaporator temperatures in different months at Adana city located in the southern region of Turkey. They found that at $0^{\circ} \mathrm{C}$ evaporator temperature, the maximum compressor power 
consumption was obtained as $2.53 \mathrm{~kW}$ at 15:00 PM on August 23. The required photovoltaic panel surface area was to be around $31.26 \mathrm{~m}^{2}$.

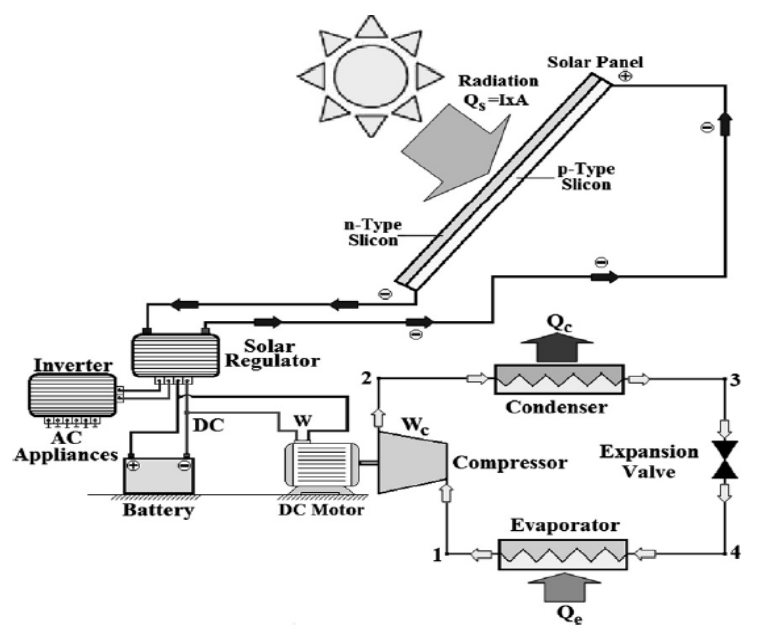

Figure 1: Solar Power Vapor Compression Refrigeration System for Hourly Simulation [6]

Cherif, A. and Dhouib, A. [7] performed the dynamic modeling and simulation of a photovoltaic refrigeration plant by using hydraulic storage (latent heat storage). By using hydraulic or latent heat storage, they remove the battery bank from photovoltaic solar refrigeration plant. They analyzed the performance of a battery-less refrigeration system in different environmental condition and then compare performance between hydraulic storage refrigeration plant and battery storage refrigeration plant.

Mba E. F. et al. [8] presented a photovoltaic mathematical model is presented by using Mat Lab. This refrigeration system consist of a DC power operated compressor, a $12 \mathrm{~V}$ battery, a solar panel and a charge control unit to prevent overcharging and deep discharging. In this system electrical analogy was performed; the input of one component will become the output of other component. The mathematical simulation was performed by using Mat Lab. This simulation was performed for 12 hours period and found that with increasing voltage the size of battery will decrease. This whole analysis was done for the KC65T photovoltaic panel and from mathematical modeling, it found that SPV panel more behaves like a current source rather than a voltage source. On increasing the solar panel insulation the power output also increased because of increasing the current at constant voltage (14.2 V).

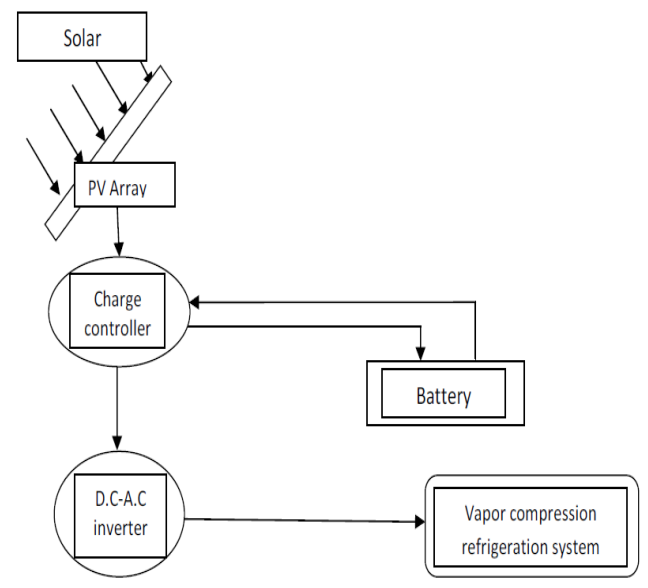

Figure 2: A DC Power Operated Refrigeration System [8] 
Kim, D. and Ferreira, C. A. I [9] presented a different type of refrigeration system in which solar energy as an input power. They determined that Coefficient of performance of a single absorption system is higher than single effect adsorption system and double effect absorption system. Although thermo-mechanical and photovoltaic solar refrigeration system has good COP than absorption system but their initial installation cost is very high. Desiccant system is more costly than other refrigeration systems.

Kablanis, S. and papanastasiou, N. [10] modified a conventional refrigerator with the help of SPV panel and then analyzed the performance of this modified refrigerator. The main modification in this refrigerator is that instead of $\mathrm{AC}$ compressor DC compressor is used so there is no need of inverter to convert DC power into AC power. To operate this DC compressor a small power battery is required and to protect this from overcharging and deep discharging a charge control unit is used. The main advantage of this modification is that energy consumption per day is decreased up to1.53 kwh when this system is operate 15 hours per day. To reduce the cable loss maintained the distance between SPV panel and charge control unit is $1.5 \mathrm{~m}$, battery and charge control unit is $1.5 \mathrm{~m}$ and charge control unit and refrigerator is $6 \mathrm{~m}$.

The above studies have helped us to develop and design a portable photovoltaic solar refrigeration system and evaluating its performance for the sole purpose of its suitability for vaccine preservation. The block diagram of our system is simple and self-understandable as given below:

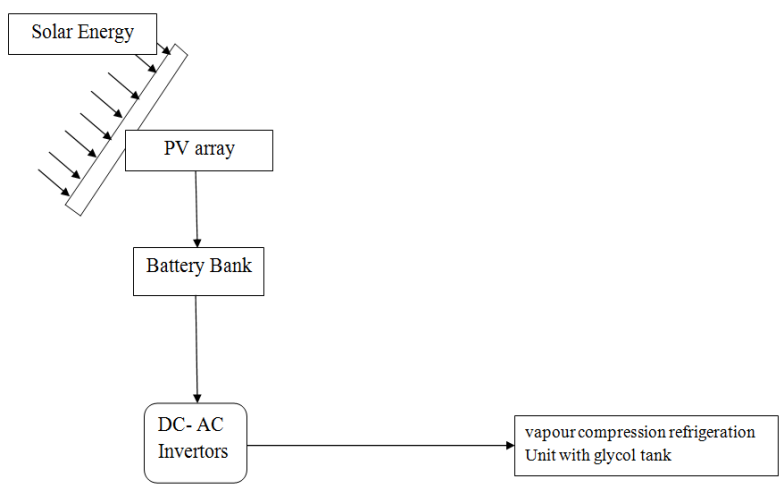

Figure 3: Photovoltaic Solar Refrigeration System

\section{FABRICATION METHODS}

A PV- refrigerator system is presented in figure-3 is the combination of five components (1) Refrigeration unit (2) Battery Bank (3) inverter (4) solar Panel (5) moving Frame.

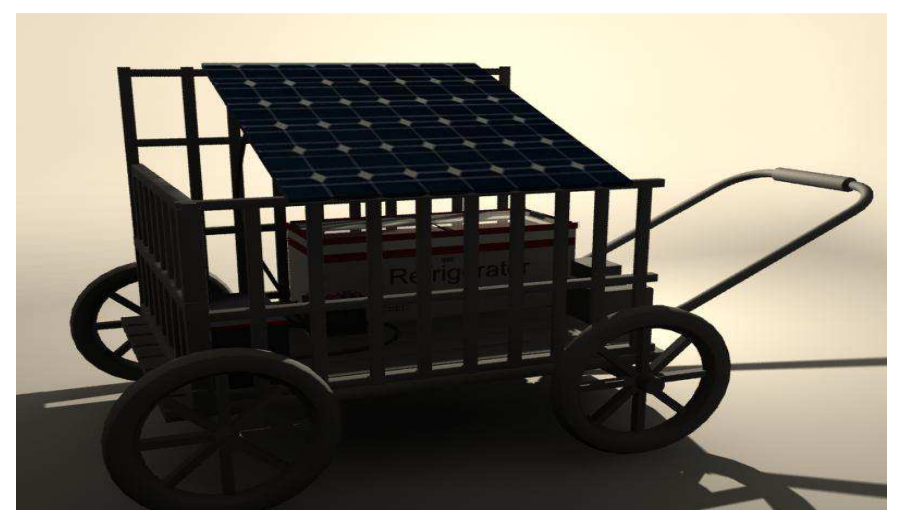

Figure 4: A Portable PV Solar Refrigeration System for Vaccine Preservation 


\section{Refrigeration Unit}

A simple vapor compression refrigeration cycle is used as a refrigeration unit, which are having following parts: -

\section{Steel Tank}

There are two tanks

\section{Outer Tank}

A thick 14.47 " $\times 21.25$ " $\times 14$ " outer steel tank with base in which $15 \mathrm{~kg}$ mild steel sheet is used to make this tank.

\section{Inner Tank}

A thin 8 " $\times 14$ " $\times 10$ " inner steel tank in which $15 \mathrm{~kg}$ mild steel sheet is used to make this tank. This is actually that space in which vaccine will be kept. The capacity of this inner tank is approximately 25-30 liters.

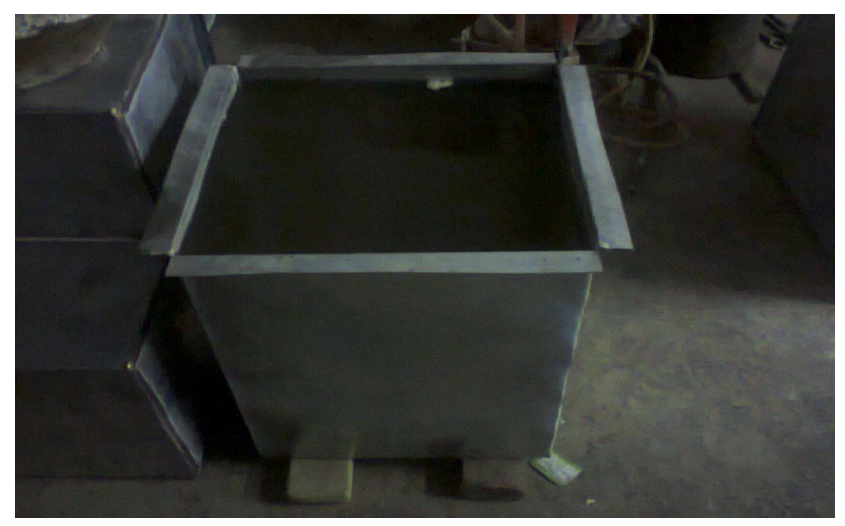

Figure 5: Inner Tank of Refrigeration Unit

\section{Accessory Box}

An accessory box is also attached with this refrigeration unit on the backside to keep extra items other than vaccines.

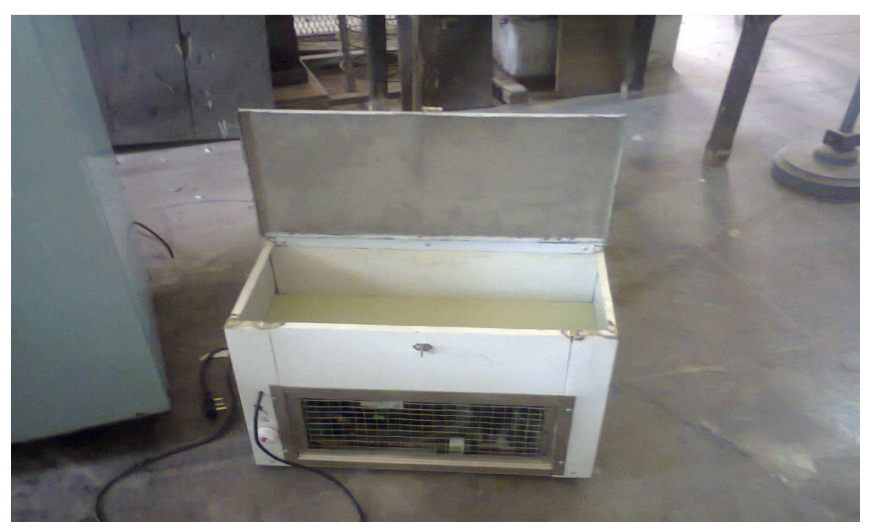

Figure 6: An Accessory Box on Backside of Refrigeration Unit

\section{Design of Evaporator}

A 100 feet long 5-16 no. (the diameter of thecooling coil is 5/16 inch) copper tube is used to make evaporator. This 100 feet long pipe is wrapped around inner steel tank. The low temperature low-pressure liquid R134a refrigerant is 
passed through this copper coil. By taking the heat it converts to vapor refrigerant and this vapor refrigerant goes to a compressor.

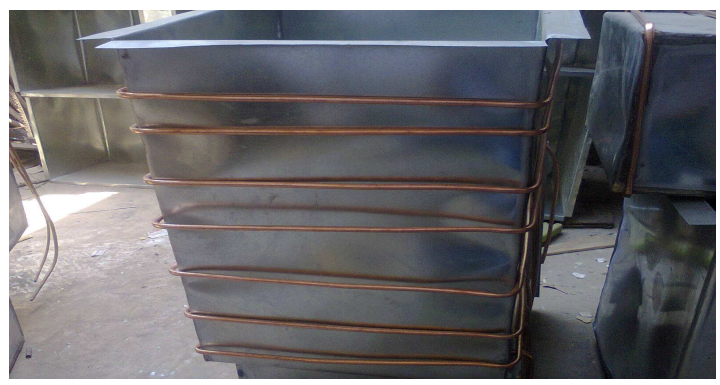

Figure 7: Evaporator

\section{Design of Compressor}

The low pressure and temperature vapor R 134a refrigerant comes from the evaporator is compressed to a high pressure and temperature vapor refrigerant by compression. This high pressure and temperature vapor refrigerant goes to a condenser. A hermetically shelled THK compressor model no.1340 is used for compression purpose. Details of the compressor are given below:

Table 1: Specifications of Compressor

\begin{tabular}{|l|c|}
\hline \multicolumn{1}{|c|}{ Manufactured by } & Tecumseh \\
\hline Model no. & THK 1340 \\
\hline Number of cylinder & 1 \\
\hline Displacement per revolution & $4 \mathrm{cc}$ \\
\hline Cooling cpacity & $350 \mathrm{btu}$ \\
\hline Rated condition current & $0.67 \mathrm{amps}$ \\
\hline Power & $90 \mathrm{watts}$ \\
\hline Weight & $7.7 \mathrm{~kg}$ \\
\hline
\end{tabular}

\section{Design of Condenser}

When the high-temperature high-pressure vapor $\mathrm{R} 134 \mathrm{a}$ refrigerant comes from the compressor and passes through the condenser its convert into high temperature high pressure liquid refrigerant by condensation process. A 7 " $\times 8$ " two row 12 pipe condenser is used for condensation purpose.

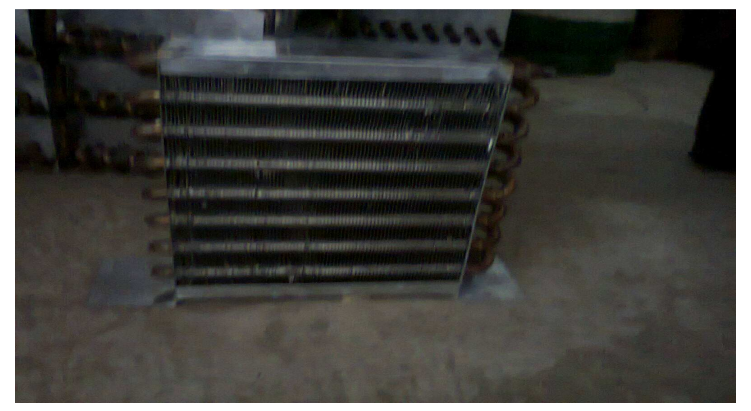

Figure 8: A 7"×8” Two Row 12-Pipe Condenser

\section{Design of Expansion Device}

When the high-pressure high-temperature liquid refrigerant comes from the condenser and passes through the expansion device an isenthalpic expansion will take place. The high-pressure high-temperature liquid refrigerant converts 
into low-pressure low-temperature liquid refrigerant. The capillary tube is 11 feet long, 036 no (diameter of this capillary tube is 0.0036 inch.).

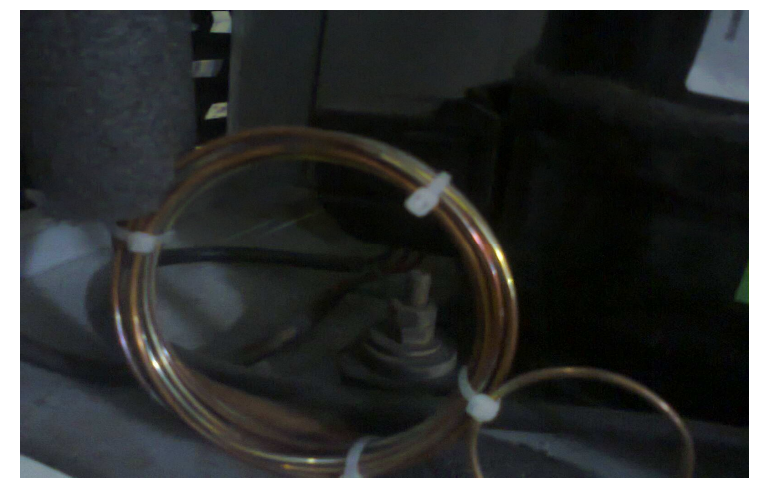

Figure 9: An 11 Feet Long 036 No Capillary Tube

\section{Design of Fan}

In this project a10-watt fan is used for enhancing condensation rate.

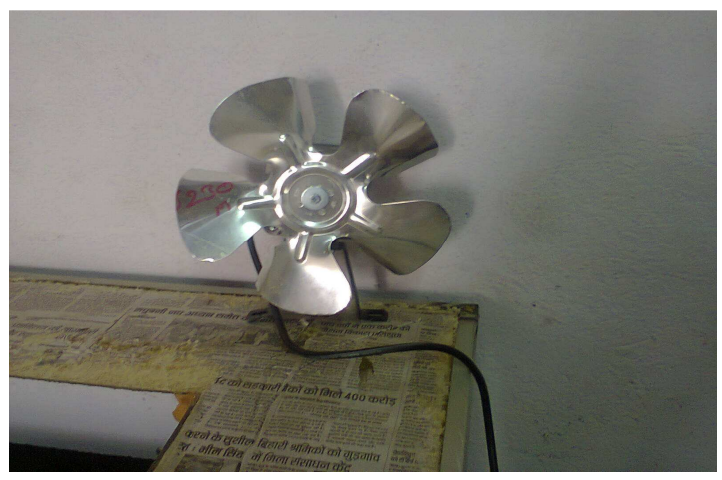

Figure 10: A 10 W Fan

\section{Thermostat}

A thermostat is used to monitor the temperature.

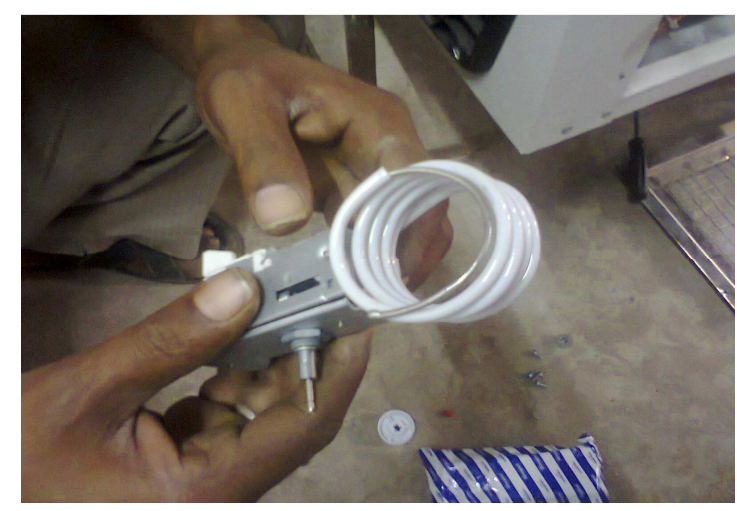

Figure 11: A Thermostat used to Monitor the Temperature

\section{Charging of Refrigerant}

In this project $250 \mathrm{ml} \mathrm{R} 134 \mathrm{a}$ is the used as a refrigerant. R134a is latest refrigerant used nowadays, It is the ecofriendly refrigerant. 


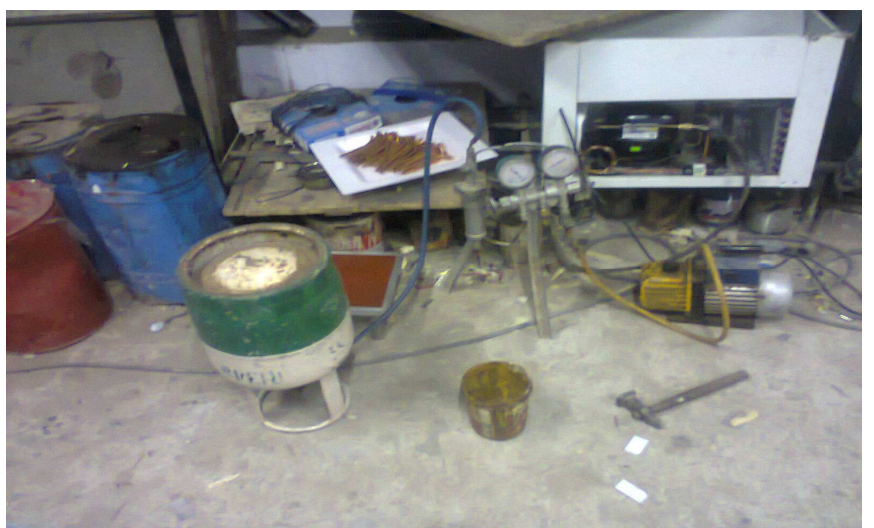

Figure 12: Charging Procedure of Refrigerant R134a

\section{Design of Insulation}

PUF (Poly Urethane Foam) is used as an isolating material. Filling the PUF is a difficult task. $5 \mathrm{~kg}$ PUF is filled between tanks. 2.5 " thick layer is formed between tanks.

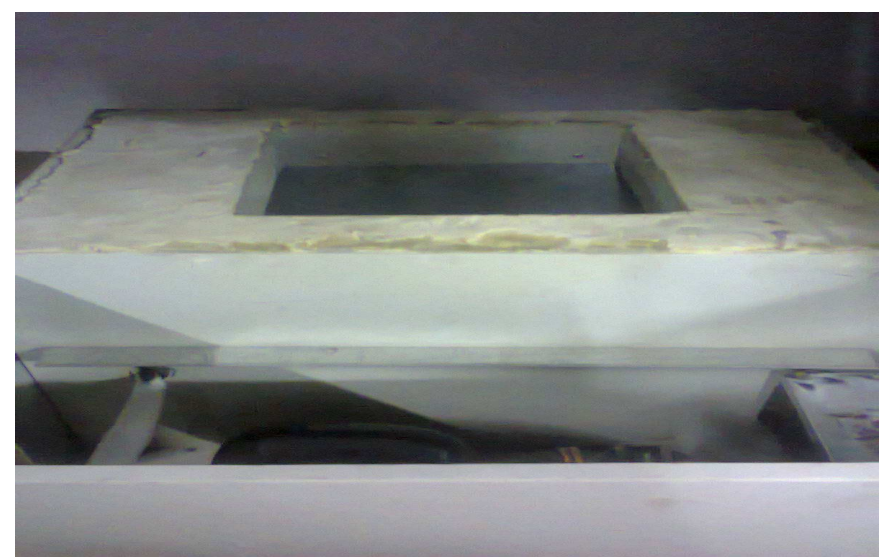

Figure 13: A 2.5" Layer of PUF is Formed as an Insulating Material

\section{Battery Bank}

A $75 \mathrm{Ah} 12 \mathrm{~V}$ Exide battery is used in this project. DC power delivered by the solar panel is stored in this battery. This battery is used to stabilize current and voltage during fluctuations of solar power.

\section{Photovoltaic Arrays}

A $125 \mathrm{~W}$ model No-HB125 is used on the upper side of frame. The PV arrays are at $45^{\circ}$ angles in a south direction so maximum power is generated. A basic solar PV panel consists of connected PV cells, which contain a semiconductor material covered by protective glass connected to a load. When sunlight hits the semiconductor, electrons get excited. These excited electrons are separated by an internal field inherent in the semiconductor and collected into an external circuit generating electricity. Several connected PV cells form a PV module; connected modules form a PV array.

\section{Inverter}

A 650 VA Microtech Inverter Is Used In This Project: There are three major work of inverter:

AC compressor is used in this project. The power delivered by solar panel is DC. This inverter converted DC power of solar panel into AC. 
- A charge control unit is also attached with this inverter to protect the battery from overcharging and deep discharging.

- $350 \mathrm{~W}$ powers are required for starting the compressor. The power delivered by the $650 \mathrm{VA}$ inverter is approximately $550 \mathrm{~W}$ so this inverter is sufficient to start the compressor.

Frame

The size of the solar panel is $26 " \times 52$ " and the size of the refrigeration unit is $24.5 " \times 21.25 " \times 14$ ". So we have selected the base of the frame is $28^{\prime \prime} \times 52^{\prime \prime}$. To maintain the angle at $45^{\circ}$ one edge is raised up to height 24 " and other height is $14 "$

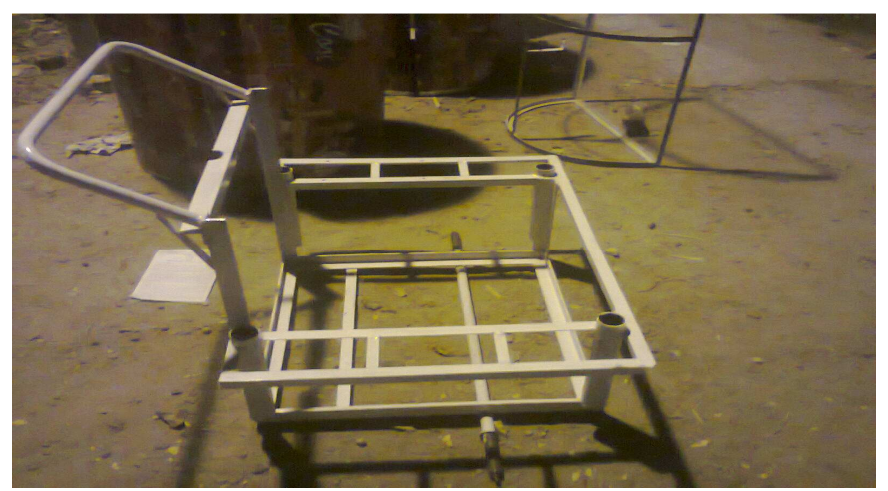

Figure 14: Frame

\section{RESULTS AND ANALYSIS}

\section{LOAD ANALYSIS}

\section{Compressor}

A 90Watts modal No-THK 1340 is used as the compressor of company Tecumseh Refrigeration Equipment.

- Input power $=90 \mathrm{Watts}$

\section{Fan}

A fan is used for cooling purpose of the compressor.

- Power of fan=10Watts

- $\quad$ Total power required $($ compressor + fan $)=30+10$

- $\quad=100 \mathrm{Watts}$

\section{Battery Bank}

To overcome the inertia of compressor \& fan and considering wire losses power delivered by the battery must be higher than $80 \mathrm{~W}$. So we selected a $12 \mathrm{~V} 80 \mathrm{Ah}$ rechargeable Exide battery model No-DB-12-80.

- Power delivered by battery $=\mathrm{V} \times \mathrm{I}$

- $=12 \times 80$ 
- $\quad$ = 960Watt-h

- $\quad$ Efficiency of battery=90\%

- $\quad$ Net power output $=960 \times 0.9$

- $\quad=864 \mathrm{Watt}$

\section{Photovoltaic PV Array}

We selected a 125-Watt solar panel on the topside of frame. The PV arrays are at $40^{\circ}$ angles in a south direction so maximum power is generated.

Power deliver by solar panel model No. HB12125=125Watts

\section{Inverter}

Input power of compressor is 350 Watts. So we must select an inverter, which has output power higher than 350 Watts. In this project, we selected a 650 VA micro tech inverter and power delivered by this inverter is approximately 550 Watts which is higher than 350 Watts.

\section{CONCLUSIONS}

From experimentation in our system, it has been observed that the developed system is able to maintain the required temperature range $\left(0^{\circ} \mathrm{C}\right.$ to $\left.8^{\circ} \mathrm{C}\right)$ up to 10 hours without any power supply. System developed is eco-friendly because $\mathrm{R} 134 \mathrm{a}$ is used as a refrigerant. We conclude that it is possible to use vapor compression cycle based refrigeration powered solely by solar panels for effectively preserving vaccines at remote areas. We propose using a DC compressor in place of AC compressor, which might reduce the power requirement allowing for small capacity battery and in the place of inverter, a cheaper charge control unit.

\section{REFERENCES}

1. World health organization. Vaccine storage and handling toolkit. National center for immunization and respiratory diseases (2008), 12-128.

2. Modi, A. et al. (2009). Performance analysis of a solar photovoltaic operated domestic refrigerator. Applied Energy,86, 258391.

3. Kattakayam, T. A., \& Shrinivasan, K. (2000). Thermal performance characterization of a photovoltaic driven domestic refrigerator. International journal of refrigeration, 23, 190-96.

4. Sarbu, I., \& Sebarchievici, C. (2013). Review of solar refrigeration and cooling system. Energy and Buildings, 67, $286-97$.

5. Nawaz, I. et al. (2012). Energy efficient solar refrigeration system. 21, 118-34.

6. Bilgili, M. (2011). Hourly simulation and performance of solar electric- vapor compression refrigeration system. Solar Energy, 85, 2720-31.

7. Cherif, A., \& Dhouib, A. (2002). Dynamic modeling and simulation of a photovoltaic refrigeration plant. Renewable Energy, $26,143-53$.

8. Mba, E. F. et al. (2012). Modeling and simulation of a photovoltaic powered vapor compression refrigeration system. Journal of information engineering and Applications, 2, 2110-15. 
9. Abdul-Wahab, S. A. et al.(2009). Design and experimental investigation of portable solar thermoelectric refrigerator. Renewable Energy, 34, 30-34.

10. TÜ_K-Turkish Statistic Institute. http://www.tuik.gov.tr.Ye_ilata B, I_lker Y (2006). Experimental analyses of a refrigerator system worked by Photovoltaic power. J. Eng. Mach., 558, 54-60 (inTurkish).

11. Anyanwu, E.E. (2003). Review of solid adsorption solar refrigerator I: an overview of the refrigeration cycle. Energy Conversion Management, 44:301-312.

12. Axaopoulos, PJ.,\& Theodoridis, M.P. (2009). Design and experimentalperformance of a PV Ice-maker without battery. Solar Energy, 83:1360-1369.

13. Nagaharshitha, D., and A. G. Kunal. "Remote sensing and gis applications in fruit industry." Journal of Progressive Agriculture 8.2 (2017): 89-92.

14. Dai, Y.J. et al. (2003). Experimental investigation and analysison a thermoelectric refrigerator driven by solar cells. Solar Energy Materials and Solar Cells, 77: 377-391.

15. Alam, A., \& Devnani, R. S. (1979). Equipment for production, handling and storage of potato. In Kishore, H.: Post harvest technology and utilization of potato. Proceeding of International Symposium, The International Potato Center, Region VI, New Delhi and Central Potato Research Institute, Shimla.

16. Beshada, E. et al.(2006). Design and optimization of a photovoltaic powered grain mill. Agricultural Engineering International: the CIGR Ejournal, Manuscript FP 06 002. Vol 8.

17. Eltawil, M. et al.(2006). Potato storage technology and store design aspects. Agricultural Engineering International: the CIGR Ejournal, Invited Overview, April,. No. 11. Vol. 8. 
